\title{
INDUSTRIAL RELATIONS AND LABOUR MANAGEMENT AND PRODUCTIVITY: THE IMPERATIVE FOR SUSTAINABLE DEVELOPMENT IN NIGERIA
}

\author{
Ojo Olayinka Olabimpe $(\mathbf{P h D})^{1}$ and Adedayo Adedeji Matthew ${ }^{2}$ \\ ${ }^{1}$ Department of Arts Education, Bamidele Olumilua University of Education, Science and \\ Technology, Ikere-Ekiti, Ekiti-State, Nigeria \\ Email: ojo.olayinka@bouesti.edu.ng Tel: +2348033948107 \\ ${ }^{2}$ Department of Peace and Security Studies, Bamidele Olumilua University of Education, \\ Science and Technology, Ikere-Ekiti, Ekiti-State, Nigeria \\ Email: adedayo.adedeji@ bouesti.edu.ng; Tel: +2347031537294
}

Cite this article:

Ojo O.O., Adedayo A.M. (2021), Industrial Relations and Labour Management and Productivity: The Imperative for Sustainable Development in Nigeria. British Journal of Management and Marketing Studies 4(4), 57-67. DOI: 10.52589/BJMMSUOTIEMYB.

\section{Manuscript History}

Received: 19 Oct 2021

Accepted: 9 Nov 2021

Published: 4 Dec 2021

Copyright $\odot 2020$ The Author(s). This is an Open Access article distributed under the terms of Creative Commons AttributionNonCommercial-NoDerivatives 4.0 International (CC BY-NC-ND 4.0), which permits anyone to share, use, reproduce and redistribute in any medium, provided the original author and source are credited.
ABSTRACT: Industrial relations, labour management and productivity have their roots in the industrial revolution which created the modern labour relationship by spawning large-scale industrial organizations. As society wrestled with these massive economic and social changes, labour problems aroused coupled with societal reconstruction challenges. Premised on this background, this paper is set to discuss the conceptual meaning of labour and industrial relations, assess the roles and prospects of labour in Nigeria, examine the consequential effects of labourindustrial relations and examine challenges of labour productivity and management in Nigeria. The paper also discusses some frameworks for labour-industrial relations. It focuses attention on the changing structure of the labour environment and the rise of precarious working conditions orchestrated by various unrests and acrimonies from nonchalant attitudes and behaviours of government and private sectors towards labour/workers' welfare and patronage. The data for this study were collected through secondary sources. The secondary data were obtained from textbooks, journals, newspapers, internet materials and literature from academic journals in relation to the subject studied. The study adopted Industrial Relations Theory as a theoretical framework. The paper concludes that labour and industrial relations are part of the critical factors and are tools in advancing industrial productivity and attaining sustainable development in Nigeria.

KEYWORDS: Labour, Industrial-Relations, Productivity, Management, Sustainable, Development 


\section{INTRODUCTION}

From time immemorial, the world has seen many internal and external violent conflicts that dramatically affected the social, economic, and political conditions of entire populace especially the population of the workforce (labour) (Yosef Jabareen, 2013). Labour-industrial relations is imperative in terms of organizational productivity and an in-progress debate from the last few decades. The human society is full of conflict. Conflict arises as a result of disagreement between two antagonising parties and classes. With references to the industrial society, industrial conflict is the inability of parties or groups in an employment relation (employer and employees represented by their unions or groups) to reach agreement on any issue connected with the object of employer-employee interactions (Fajana, 2000). Industrial relations can be seen as a cordial relationship between labour and management.

Labour-industrial relations has its roots in the International Labour Organization (ILO) charter or articles which created the modern employment relationship by spawning free labour markets and large-scale industrial organizations. As society wrestled with the massive economic and social conflicts, labour problems arose (ILO, 1999).

Labour-industrial relations has become a major elusive and intricate problem of modern industrial societies. Labour-industrial/management progress is impossible without the cooperation of labour and pleasant-sounding relationships. Therefore, it is in the interest of all to create and maintain good relations between employees (labour) and employers (government and industry/company) (Fashoyin, 1992).

The expression 'labour-industrial relations' consists of two terms: 'labour' and 'relations'. "Labour" refers to "any productive activity in which an individual (or a group of people) is engaged". "Relations" means "the interaction or dealings that subsist within the industry between the employer and his workforce (Frenkel \& Harrod, 1995).

Labour-industrial/management relations are the interactions and dealings between employees and employers within the organizational settings. The field of industrial relations looks at the relationship between management and workforce, especially groups of workers represented by a union, i.e, Trade Union Congress (TUC), Nigeria Labour Congress (NLC), Academics Staff Union of Universities (ASUU) and so on. Industrial relations are basically the relationships between employers, employees and the government, and the institutions and associations through which such relationships are mediated.

Subsequently, labour unions take their position within the wider labour movement, which consists of several more or less closely and familiarly related organizations. All have common aims, goals and objectives - to increase or advance the cultural, material, physical, and social status of their members. Labour unions have a particular function in this, but relationships between the various parts of the labour movement differ from state to state and from time to time (Allen, 1971).

The amplification of labour organization in Nigeria in recent times inevitably necessitated a distinct connection between labour union and management. These relationships broadly speaking concern the continued existence of the firms in order to achieve the purpose for which they were instituted. The attainment of this goal is largely dependent on the relationship between management and workforce in industry. However, the formalization of industrial relations system in Nigeria does not mean that conflict has been eliminated from industrial 
relations; forces involved in conflict have become more predictable (Ayodele, 1986). Both management and workforce still hold hostile attitudes which lead to soured relationship and maximize industrial actions and crises between management and workers.

A labour relations system incorporates both societal values i.e., freedom of association, a sense of group solidarity and techniques (e.g., methods of negotiation, work organization, consultation and dispute resolution). Both public and private interests are at stake in any labour relation system. The state is an actor in the system as well, although its role varies from active to passive in different countries. The nature of the relationships among organized labour, employers and the government with respect to protection and safety are indicative of the overall status of industrial relations in a country or an industry.

\section{Conceptual Clarification}

\section{Industrial Relations}

According to Chrisantus Oden (2020), industrial relations is a system of rules which guides trade union and employers about the pay and working condition of union regulations collective agreement, arbitration awards, social conventions, management decision and accepted custom practices. In the same vein, Dunlop J.T. sees industrial relations as the complex interrelations among managers, workers and agencies of governments. Accordingly, Dale Yoder averred that industrial relation is the practice or method of management dealing with one or more unions with a view to negotiate and subsequently administer collective bargaining agreement or labour contract.

\section{Labour-Industrial Relations}

According to the International Labour Organization (ILO), labour-industrial relations deals with either the relationship between the state, employers and workers organization or the relation between the organizations. Labour-industrial relations refers to the formal relationships that exist in the institution between the workers and the management team which represents the owners (employers) of the organization or institution and the government. The labour unions are made up of various associations formed, organized and managed by the employees in the institution or organization.

Subsequently, Bethel and others posited that "industrial relation is that part of management which is concerned with the manpower of the enterprise whether machine operators, skilled workers or managers". Manpower of the enterprise can thus be classified as management and workers or employers and employees, and industrial relations can thus be treated as relations between the employers and workmen. According to V. Agnihotri, "the term labour-industrial relations explains the relationship between employees and management which stems directly or indirectly from union-employer relationship." V.B. Singh also postulated that "labourindustrial relations is an integral aspect of social relations arising out of employer to employee interaction in modern industries, which are regulated by the state in varying degrees, in conjunction with organized social forces and influenced by prevailing institutions.

According to Wikipedia, labour-industrial relations is the complex interrelation between employers and employees, labour/trade unions, employers organizations and the state. Furthermore, the relationship encompasses one between the organized labour, i.e., unionized labour and their employers either in the industry or with the state. The relation's scope extends 
from employment situations, conditions of employment and payment, labour-management relationship (vertical and horizontal), the structure of such relationship and the degree of such relationship.

Therefore, the term labour-industrial relations refers to the interactions between employees as represented by Labour Unions such as Nigeria Labour Congress (NLC), Trade Union Congress (TUC) and so on, and their employers such as government, private establishment and organization and a few others. Labour-management relations is aimed at the efficient use of human and material resources to increase the productivity of an organization.

\section{Labour}

Labour (workforce) is a set of people engaged in or available for work, either in a country or area or in a particular firm or industry. It also refers to workers as a group. Workers in an industry sell their own labour in exchange for an income they negotiate with the management. The Oxford English Dictionary defines labour as "the people who work or are available for work in a country or countries." From the Marxist point of view, the only commodity or property that can be used by the masses or the working class to have their basic needs met is through selling its labour for wages/salary to the capitalist or, rightly put, its employer. The employer and the employee (labour) agree to a contract in the labour market with conditions centred on the wages, time of work, incentives and a few others which, upon agreement, the labour sells its labour (capacity to work) to the employers to set economic and financial rewards, i.e., salary or wages.

\section{Industry}

An industry is the whole of all economic activities by companies, people, organizations involved in the production of goods and services for a particular field. Industries are usually categorized by the good and services they manufacture or assemble. An industry is also a group of companies that are related based on their primary industrial activities. In modern day, there are dozens of industry classification. Industry classifications are classically grouped into three (3), namely primary, secondary and quaternary industry.

\section{Management}

Management entails the activity that subsume the skillful integration of both human and material resources, having control and direction over them in order to achieve the organizational objectives. A manager makes use of the material and human resources, pooling them together, controlling them effectively in order to achieve the objectives and goals of the organization.

\section{LITERATURE REVIEW}

\section{Labour}

Labour in most situations and conditions is frequently looked at as the most effectual of all factors employed for the establishment of wealth and the prospective to build up and assist as a force to all other resources (Yesufu, 2000). The Oxford Dictionary postulates labour as bodily and mental toil tending to the supply of wants of its commodity. Labour has the same meaning 
with worker, which means any employee who enters into a contact for mutual work. According to the Encyclopaedia Britannica, labour also could be likened to several human processes and activities. The word in basic sense is related to employment, unemployment, work, trade unionism and organizational relations.

In both private and public institutions and organizations, a lot of emphasis has been put on labour productivity. One reason for this emphasis on labour productivity is possibly because labour is a key resource which is universal (Oyeranti, 2003). There are some other reasons to justify the use of labour for the purpose of productivity: Labour is the only means of production that has known control over its inputs to output; labour is the most substantial factor of production; and labour is the most measured factor of production (Ayeni \& Awe, 2010, ILO, 1996).

\section{Industrial Relations}

The concept of industrial relations is recent and can be traced to the work prepared by Professor John Dunlop in 1958 titled Industrial Relations System. Dunlop developed one largely influential framework for explaining industrial relations. He postulated industrial relations system as "an analytical subsystem of the society" which entails a study of problems posed by wages, employment and conditions of service to which both workers and their establishment and organization, the government and its agencies, and at all times the general public, must find solution (Dunlop, 1958).

Subsequently, industrial relations are connected with the methodical study of all areas of employment (Fajana, 2000). It has been debated to have a related connotation with labour relations. It can be averred that industrial relations is a leading factor that affects productivity directly or indirectly. Industrial relations can be referred to as a combination and mixture of interactions that happen between employers and employees in an organization (Yesufu, 2000). It is also thought that the fundamental issue in all organizations is developing and maintaining an effective and harmonious relationship. For this to be achieved, policy making by consultation, delegation and group dynamics must be implemented (Englama, 2001).

\section{Theoretical Framework}

This aspect of the study discusses the theory that forms the framework with which the research works is built. For the purpose of this study, the theory used is the Industrial Relations Theory.

\section{Industrial Relations Theory}

Industrial relations scholars such as Alan Fox have described three major theoretical frameworks, which contrast in their understanding and analysis of workplace relations. The three views are generally known as Unitarism, Pluralism, and the Radical or Critical School. Each offers a particular perception of workplace relations, and therefore interpret such events as workplace conflict, the role of unions and job regulation differently. The perspective of the critical school is sometimes referred to as the conflict model, although this is somewhat ambiguous as pluralism also tends to see conflict as inherent in workplaces, institutions and organizations. The pluralist perspective supports that conflict is inherent in dealing with labourmanagement relations since different organizations and institutions have different opinions in day-to-day operations. Consequently, the role of management would lean less towards enforcing and controlling, and more toward persuasion and coordination in the post-conflict 
period. Trade unions are deemed legitimate representatives of employees; conflict is resolved through collective bargaining.

\section{Historical Analysis of Nigeria Labour-Government Relation and Industrial Actions in Nigeria}

The history of Nigeria labour-government relation could be traced to the pre-colonial government, the employer of labour and the Nigerian labour in the government offices, ministries and departments which can be described as that of exploiter-exploited relationship. But with the independence of Nigeria in 1960, the relationship between the government and the labour changed to that of partners in progress. The post-independence era called for the synergy and the concerted effort of the government and its executing agencies, i.e., the civil service and public service working towards speedy national development and a change in the tune of Nigeria polity.

However, all hope for the changes was brought to life and more closer to reality by the creation of more structured and well organized labour unions in the country. With the creation of Nigeria Labour Congress (NLC) in 1978, the Academic Staff Union of Universities (ASUU) in 1979 and some other Nigerian labour unions, the structure of labour-government changed and was reinforced, and resultantly, there are provisions for unaided two-channels of communication between the government and the labour union(s). The communication centres mostly on salient issues especially those affecting the labour such as wages and salaries (either its increment or the demands for payment of backlogs of unpaid salaries), provision of good working conditions and so on.

Subsequently, since 1960 till date, the Nigerian government (both military and civilian government at the Federal and State level) has cultivated a zero-tolerance for the agitations and demands of the Nigerian labour and when some of demands are accepted, the government has failed to fulfil their promises to the labour unions. The negligence of the government in appreciating the values of Nigerian labour unions regardless of their active and meaningful contributions towards national development, and the failure of government to fulfil the demands of the labour - especially those affecting their economic and social well-being - has prompted the Nigeria labour unions to embark on industrial strikes either for a warning or an actual one.

To give credence to this above stated point, below is a list of industrial strikes of Nigeria Labour Congress from 1981-2012.

\begin{tabular}{|l|l|l|l|}
\hline Year & $\begin{array}{l}\text { Administration } \\
\text { and Regime }\end{array}$ & Purpose & Number of Days \\
\hline May 1981 & $\begin{array}{l}\text { Shehu Shagari } \\
\text { Administration }\end{array}$ & $\begin{array}{l}\text { Poor Management of the } \\
\text { economy by the Federal } \\
\text { Government and minimum } \\
\text { wages issues }\end{array}$ & Two days \\
\hline May 1988 & $\begin{array}{l}\text { Ibrahim } \\
\text { Babangida } \\
\text { Regime }\end{array}$ & $\begin{array}{l}\text { Opposition to structural } \\
\text { adjustment programme of the } \\
\text { administration }\end{array}$ & $\begin{array}{l}\text { Structures dissolved } \\
\text { by Military } \\
\text { Government }\end{array}$ \\
\hline
\end{tabular}


British Journal of Management and Marketing Studies

ISSN: 2689-5072

Volume 4, Issue 4, 2021 (pp. 57-67)

www.abjournals.org

\begin{tabular}{|c|c|c|c|}
\hline July 1994 & $\begin{array}{l}\text { Sani Abacha } \\
\text { Regime }\end{array}$ & $\begin{array}{l}\text { Agitation for the restoration of } \\
\text { democracy }\end{array}$ & $\begin{array}{l}\text { Structures dissolved } \\
\text { by Military } \\
\text { Government }\end{array}$ \\
\hline January 2004 & $\begin{array}{l}\text { Olusegun } \\
\text { Obasanjo } \\
\text { Adminstration }\end{array}$ & The reintroduction of fuel tax & Five days \\
\hline June 2007 & $\begin{array}{l}\text { Late Umaru } \\
\text { Yaradua } \\
\text { Administration }\end{array}$ & $\begin{array}{l}\text { Increase in the pump price of } \\
\text { fuel from } 65 \text { to } 75\end{array}$ & Four days \\
\hline January 2012 & $\begin{array}{l}\text { Goodluck } \\
\text { Jonathan } \\
\text { Administration }\end{array}$ & $\begin{array}{l}\text { Removal of fuel subsidy and } \\
\text { increase in pump price from } \$ 65 \\
\text { to } \$ 138\end{array}$ & Five days \\
\hline May 2016 & $\begin{array}{l}\text { Muhammadu } \\
\text { Buhari } \\
\text { Administration }\end{array}$ & $\begin{array}{l}\text { Increase in the pump price of } \\
\text { fuel from } 86.50 \text { to } 145\end{array}$ & Four days \\
\hline $\begin{array}{l}\text { September } \\
2018\end{array}$ & $\begin{array}{l}\text { Muhammadu } \\
\text { Buhari } \\
\text { Administration }\end{array}$ & Minimum wage demands & Two days \\
\hline
\end{tabular}

\section{Impacts of Industrial Actions and Crises on Labour-Industrial Relations in Nigeria}

The organization in the institution where the labour works when management takes place and where the whole relationship between the labour-management takes place are not operational outside the influence of the ecological factors. Such ecological factors are the state itself, its political practices, the socio-cultural arrangement, the economic condition and level of development, the level of compromise and unity in diversity; all these to a great extent influence labour-management relationships (vertical or horizontal) in crises and its impact. The labour-management relation and the working environment are not insulated from the great effect of crises such as various industrial actions that engulfed Nigeria since 1960 occasioned by Academic Staff Union of Universities' strikes, health workers' strikes, judicial staff workers' strikes and so on. It is expected that if an industry has inadequate staff welfare, industrial actions and crises are inevitable.

The relationship between the labours (horizontal relation) and the vertical relation between the labour-management will be strained especially where the top managers are from the tribe or ethnic group that are causing the conflict. It is expected that social effect and manifestation of the conflict will soon generate in the industry, thereby worsening and breaking up the structural relationship in the industry. The effects may be latent or manifest, but what remains constant in the labour-management relationship is what it breathes (gives out) to the public and receives from the public.

Labour industrial actions and crises change economic activity in a number of ways. These changes in economic activity become entrenched after strikes have ended. The available evidence found within the scope of the suggests that the extent to which changes in economic activity become entrenched after crises and industrial actions depends on how developed a country was prior to the conflict. For instance, in Nigeria, during a series of ASUU, NLC, TUC, JUSUN, and other labour unions industrial actions, there are some specific economic challenges faced by the country, its states, institutions, organizations (private and public 
sectors) and the entire workforce during and after the industrial actions. They include the following:

a. Private Sectors Decline: These often continue in crises period, due to skills shortages and problems with infrastructure which make normal operations difficult.

b. Labour Market Issues: Industrial actions and crises often cause an increase in unemployment, lack of empowerment and a rise in informal activities. These changes generally persist due to a lack of opportunities.

c. Illicit Economic Activities: Industrial actions and crises tend to result to an increase in illicit economic activities. These illicit economic activities tend to continue as those who have been profiting from them are reluctant to abandon uncreative sources of income.

d. Other economic impacts of industrial actions and crises on labourmanagement/industrial relations include capital flight, small tax base, inflation, and so on.

Industrial actions and crises have adverse effects and deteriorating relations at the workplace have adverse impacts on the overall productivity of organizations. It has added to the building up of an environment of distrust among labour and hampers their motivation levels.

\section{Roles and Prospects of Labour in the Society}

The roles of the labour in the society are so enormous that they cannot be ruled out. For instance, taking a cue from what transpired immediately after the Nigeria Civil War that lasted for 30 months (1967-1970), the then military government promulgated a state policy and programme called the 3Rs (Reconciliation, Rehabilitation, and Reconstruction). Looking deeply into this 3 Rs programme, it is observed that government and the key practical actors will not be the ones to implement it directly, but the bureaucrats, and if we talk about the bureaucrats in this programme, the job is mostly on the labour, while the top managers managed the whole process.

In a nutshell, when there is a good working environment, incentives from the government, good and unaided labour-management relation and smooth relation with the state, then it is expected of the labour and the top managers to contribute their quota to the national development and stability. To restore the dignity of human life and properties which is a major social conflict, the labour in that sector must be well organized, and relationship must be maintained cordially, e.g., labour union such as Nigeria Labour Congress (NLC), Trade Union Congress (TUC) and others in that categories. These have to be put into consideration for greater and positive output towards national growth and development.

\section{Consequential Effects of Labour-Industrial Actions and Crises in Nigeria}

In a state like Nigeria, where the living conditions of workers are not being taken seriously and prioritized, where the economic life of labour is miserable and unaccounted for, the labour through unionized agitations in their forum, such as Nigeria Labour Congress (NLC), Trade Union Congress (TUC) and so on, threaten to strike or embark on industrial actions and if the government refuses to concede and heed their demands, industrial actions such as strike and protest ensue. In such a scenario, with valid past events attesting to this fact, the effects of strike 
or any other labour-l industrial action taken to make the government yield may bring the following (especially when the interests of the labour and the public synergize):

a) Social relations strained: Social suspicion and distrust becomes the order of the day, especially internal relationships within industries.

b) Economic doldrums and paralysis.

c) Social and economic activities clampdown: This threatens socio-economic prosperity and prospects for development.

Other consequences of labour-industrial actions and crises in the society are

a) The effects on the general public as key sectors are affected such as health sectors (during incessant strike of medical practitioners), unwarranted and unjust detainment of suspected criminals (as a result of strike of Judicial Staff Union of Nigeria, JUNSUN) and so on.

b) Ethnic hostility: This occurs where there are people from different ethnicities in one industry.

c) Discouragement by the labour to work productively: This has effects on nation building and national development.

\section{Challenges of Industrial Relation and Labour Management and Productivity in Nigeria}

Nigeria civil service, private workers/employers, the bureaucrats, the security operatives and apparatus, and other employers especially those working in the government ministries, departments, agencies/parastatals, offices and industry face a great deal of challenges threatening if not sabotaging the productivity and efficiency of labour especially in postconflict era.

The following challenges are seen if careful analysis is done to the nature of labour productivity in post-conflict era in Nigeria starting from the colonial period to this present time:

a) Poor political will of leaders (especially political office holders and political administrators of government ministries) to cooperate and listen to the agitations of workers and attend to them. Examples are agitation over IPPIS of Academic Staff Union of Universities (ASUU), financial autonomy agitation for judiciary workers and legislative workers, and operational autonomy for local government and others.

b) Poor economic conditions of the workers will surely reduce job satisfaction which in turn will affect productivity and efficiency.

c) Inadequate and unhealthy working environment for the labour.

d) Inadequate or obsolete technologies: Old-fashioned method of productivity still used, coupled with obsolete technological base hampers labour productivity in Nigeria.

e) Lack of infrastructural facilities for the labour in their respective place of works; they are in poor conditions. 
f) Poor economic funding of programmes expected to be carried out by the labour - policy made for implementation but no proper funding for its execution.

g) Too much pressure from the government, the public, relatives, clients and patrons for bribes and other benefits - which are morally unacceptable - from the contractors or private workers make them unproductive, and where they are productive under much pressure for money and attention, poor or substandard and superficial works are delivered.

h) Corruption and poor working culture of some labour and personality variables of laziness and carefree lifestyle.

\section{CONCLUSION}

Based on the findings of the study, it is clear that the labour-industrial relation is still very weak across all sectors including private and public sectors in Nigeria. The study observed that labour in the various sectors, institutions and organizations in Nigeria is unsatisfied with their management regarding working conditions, wages for their work, the behaviour of the managers at the workplace, and the welfare packages provided to the staff for their well-being. This predicament of unsatisfied labour in the industries and institutions caused the low level in the productivity of the organizations.

The capitalist oriented economy has brought about the labour-management dichotomy where there is an imbalance in relationship inside the organization and with the outside agency or institutions, such as the government, and the unbalanced structure of relationship has generated and may continue generating both internal and external socio-economic and political problem if attention is not given to the management-labour or labour-industrial relation, the social environment and the roles of the labour in the society.

In order to make the labour-management productive and strengthen efficient and valuable socio-economic development of the nation-state, the following should be done by all stakeholders involved in the labour-management relations: restructuring the labourmanagement relation to promote balance and free flow of relation vertically and horizontally; ensuring unhindered flow of communication between top-managers and the labour and also with the government and horizontal communication; putting in place measures to provide for the socio-economic welfare of the workers in order to forestall future agitations that may lead to strike; reorientation of the labour-management on how to maintain unity in diversity, cohabitation and ethnic compromise and health living for the sake of the state and individual development; and ensuring that all equipment, technological appliances, gadgets, materials, facilities, and the host of others are provided for the labour, together with standard social infrastructure and economic incentives in order to promote productivity and job satisfaction. 


\section{REFERENCE}

Allen, V. (1971). The Sociology of Industrial Relations, London, Longman

Ayeni, R. \& Awe, A. (2010). Emperical investigation into industrial relations and national productivity in Nigeria. Ozean Journal of Applied Sciences. 3(3): 331-339.

Ayodele, S. (1986). Leadership and Relations towards Industrial Peace in a Recessional Economy, London, Longman

Dunlop, J. (1958). Industrial Relations Systems. New York: Henry Holt and Company Englama, A(2001). "Unemployment concepts and issues," Bullion, Central Bank Nigeria. Fajana, S. (2006). Industrial relations in Nigeria. Labofin and Company.

Fashoyin, T. (1992). "Industrial Relations and African Development. New Delhi: South Asian Publishers.

Frenkel, S. \& Harrod, J. (1995). "Industrialization and Labour Relations: Contemporary Research in Seven Countries. Ithaca, NY: ILR Press.

International Labour Organization (ILO). (1999). Internal Labour Organization. Human development report.

Oyeranti, G.A. (2003). Concept and Measurement of Productivity.

Yesufu, T.M. (1982). Dynamics of Industrial Relations. The Nigeria Experience, University Press, Ibadan Limited.

Yesufu, T.M. (2000). The human factor in national development: Nigeria, Spectrum Books Limited, Ibadan, Nigeria.

Yosef, J (2013). Conceptualizing "Post-Conflict Reconstruction" and "Ongoing Conflict Reconstruction" of Failed States. International Journal of Politics, Culture, and Society. 26, 107-125. 